\title{
Distribution and Abundance of Gelatinous Zooplankton in Coastal Waters of Port Blair, South Andaman
}

\begin{abstract}
Study on gelatinous zooplankton distribution, abundance and species composition was undertaken during March'13, April'13, August'13, December'13 and February'14. A total of 16 species belonging to 10 taxa were recorded of which 8 taxa belonged to Station 1 and 9 taxa to Station2 respectively. Hydromedusae $\left(6.01 \mathrm{ind} / \mathrm{m}^{3}\right)$ was found to be the most dominant taxa recorded followed by Chaetognaths $\left(1.64 \mathrm{ind} / \mathrm{m}^{3}\right)$, Larvaceans and Siphonophores showed a similar abundance $\left(1.21 \mathrm{ind} / \mathrm{m}^{3}\right)$. Station 1 had high species richness $(\mathrm{d}=15)$ than Station2 $(\mathrm{d}=9)$. Distribution and abundance of gelatinous zooplankton was regulated by hydro-biogeographic parameters. Gelatinous zooplankton taxa were found to be influenced by single or multiple abiotic and biotic factors. The absence or lower limit of required factors was responsible for restricted distribution of species such as Pleurobranchiapileus, Bassiabassensis, Eireneceylonensis, Eirenehexanemalis, Helgicirrahamalayensis and Octophialuciumindicum. Clustering of Station1 and Station2 samples (similarity value $23.01 \%$ ) was observed due to occurrence of similar taxa in both stations. Cluster with least similarity and highest similarity found in Station1 indicating periodic blooming of gelatinous zooplankton taxa. Lack of literature on this ignored taxa and their noxious effect reported all over the world point out necessity of this study.
\end{abstract}

Keywords: Gelatinous zooplankton, Nematocyst, Eutrophication, Diversity, Distribution, Andaman sea
Volume 5 Issue 6 - 2017

\author{
G Padmavati, ${ }^{2}$ FuadSaneen CVI \\ 'Department of Ocean Studies and Marine Biology, Pondicherry \\ University, India \\ ${ }^{2}$ Department of Ocean Studies and Marine Biology, Port Blair \\ Pondicherry University, Andaman \& Nicobar Islands
}

Correspondence: G Padmavati, Department of Ocean Studies and Marine Biology, Port Blair Pondicherry University, Andaman \& Nicobar Islands, India, Email padma190@rediffmail.com

Received: May 30, 2017| Published: June 22, 2017

\section{Introduction}

Andaman and Nicobar islands are emergent remnants of tertiary mountain chains, which originated as a cause of geological upheaval, along with volcanic and oceanic influences. The Andaman Islands are the extension of the submerged Arakan Yoma Mountain range of Myanmar and the Nicobar are the continuation of the Mentawai Islands to the south and southeast of Sumatra. These two island groups situated in the Bay of Bengal span $6045^{\prime} \mathrm{N}$ to $13041^{\prime} \mathrm{N}$ and 92012 ' E to 930 57' $\mathrm{E}$. These island ecosystems are well known for its biodiversity, fishery potential and tribal populations which make it one of the best tourist destinations in the world. Currently, a high degree of anthropogenic activity is fading the bio-wealth of Andaman Sea. Andaman Sea cannot be excluded from gelatinous zooplankton (abbreviated as 'GZP' throughout this literature) studies, as these organisms enjoy a worldwide distribution.

Biological Studies on Andaman Sea are less as compared to other seas in the Indian Ocean. ${ }^{1}$ Most of the gelatinous zooplankton species are cosmopolitan to Indian Ocean; the previous studies on gelatinous zooplankton from Indian Ocean were mostly confined to any specific taxon of this wide group. Studies on Indian hydrozoa were carried out by Vannuci \& Navas et al. ${ }^{2-8}$ Till now from India: 212 species of Hydrozoa, 25 species of Scyphozoa, 5 species of Cubozoa and 600 species of Anthozoa have been reported. The 12 species of Ctenophores, among the 100-150 species known from the World Ocean, occur in the Indian Seas. ${ }^{9}$ Gelatinous zooplankton is a collective term for organisms belonging to various taxa such as medusa (both Hydromedusae and Scyphomedusae), Siphonophores, Ctenophores, Chaetognaths, Pteropods, Heteropods, Appendicularians, Salps, Doliolids and Pyrosomes..$^{10}$ All these taxa are anatomically characterized by presence of mesogleal layer, still they differ from each other in various features such as reproduction, predatory mode, and digestion etc. scarcity of studies on gelatinous zooplankton distribution is due to the fragile nature of these unique groups of organisms. ${ }^{11}$ Studies on gelatinous zooplankton population of Tamil Nadu coastal water were carried out by Pallavan. ${ }^{12}$ Apart from this study other reports from Indian Ocean waters are mainly on Hydromedusae, Scyphomedusae and new records of various gelatinous species.

Even though gelatinous zooplankton got less attention, jelly fishes (zooplanktons of phyla Cnidarian and Ctenophora ${ }^{13}$ are infamous worldwide due to their noxious effect and periodic blooming / aggregating nature. Jellyfish blooms were reported from different parts of world seas, such as Mediterranean Sea. ${ }^{14-17}$

Major factors influencing domination of gelatinous zooplankton are eutrophication (Arai et al., 2001), overfishing, ${ }^{18}$ climate change, ${ }^{19}$ and invasion of GZP. ${ }^{20}$ Noxious effects of Jellyfish blooms, affects fishery activity by clogging fishing nets sometimes damages fishing gear. ${ }^{21}$ Aquaculture rafts act as surface for attachment of polyp of hydrozoans and scyphozoans, sometimes overfeeding of the coastal aquaculture system leads to eutrophication and it ends up in jelly fish blooms and higher economic loss. ${ }^{22}$ Jellyfish ingression on water screens of Madras Atomic Power Station (MAPS) reduced plant efficiency, and resulted in shutdown of power station. ${ }^{23}$

Similar cases of power-plant shutdown, power reduction and rotary screen damage were reported by Matsueda. ${ }^{24,25}$ Jellyfishes affects tourism through its sting attacks, death and causality's are resulted by severe case and were reported by (Yesuda 2003), Fenner\& Williamson (1996). Nematocyst venoms of various species are known for it's neurotoxic, cytotoxic, haemolytic, and cardio depressive effects. ${ }^{26}$ Many species of GZP are invasive species; accidental entry of these species to a new ecosystem disrupts the ecosystem and energy flow. ${ }^{20}$ 
The current study aimed to investigate the distribution and abundance of gelatinous zooplankton, from the coastal waters of two specific areas, in Port Blair, South Andaman. Lack of literatures from Andaman Sea, on this neglected group of animals indicates the necessity of this study. Population dynamics of gelatinous zooplankton in relation to varying hydro-biographic factors was investigated throughout the study period. Taxonomic classification of gelatinous taxa from coastal waters of this island will be an asset to taxonomic studies in Indian Ocean. Ichthyoplankton monthly population variation was studied to depict the predatory force exerted by 'GZP' on fishery sector. Zoogeographic variation in species composition and species richness will be analyzed to find out the favoring factors for domination and variation in population structure of gelatinous individuals.

\section{Methodology}

Samples were collected during March, April, August, December 2013 and February 2014 from two stations viz. Junglighat (St. 1) located at $11^{\circ} 39^{\prime} \mathrm{N}$ and $92^{\circ} 43^{\prime} \mathrm{E}$. Whereas St. 2 , Burmanallah located at $11^{\circ} 33^{\prime} \mathrm{N}$ and $92^{\circ} 43^{\prime} \mathrm{E}$ (figure 1). Zooplankton nets with a mesh size of $200 \mu \mathrm{m}$ and a mouth area of $0.2 \mathrm{~m}^{2}$ were used for collection. ${ }^{27}$ The flow meter was fixed at the mouth of the net, horizontal hauling was carried at surface water for 10 minutes during day (04 $30 \mathrm{hrs)}$. Collected samples was preserved immediately to avoid autolysis by using $4 \%$ formalin, $1-2 \mathrm{ml}$ of glycerin were added to exclude the loss of quality of gelatinous samples due to formalin induced shrinkage. Physico-chemical parameters of Seawater, such as water temperature, salinity, $\mathrm{pH}$, and Dissolved oxygen were analyzed and recorded throughout the study period from both stations. ${ }^{28}$ Laboratory analysis was carried out after 7 days of preservation with glycerin allowed the specimens to regain their original size and texture. For the observation, sorting and taxonomic identification of specimens Nikon SMZ 1500 model stereoscope were used, and Nikon camera (Coolpix P6000) used for taking photographs. The classification and identification of specimens up to the lowest possible taxonomic level was done by using standard identification manuals. ${ }^{29-32}$

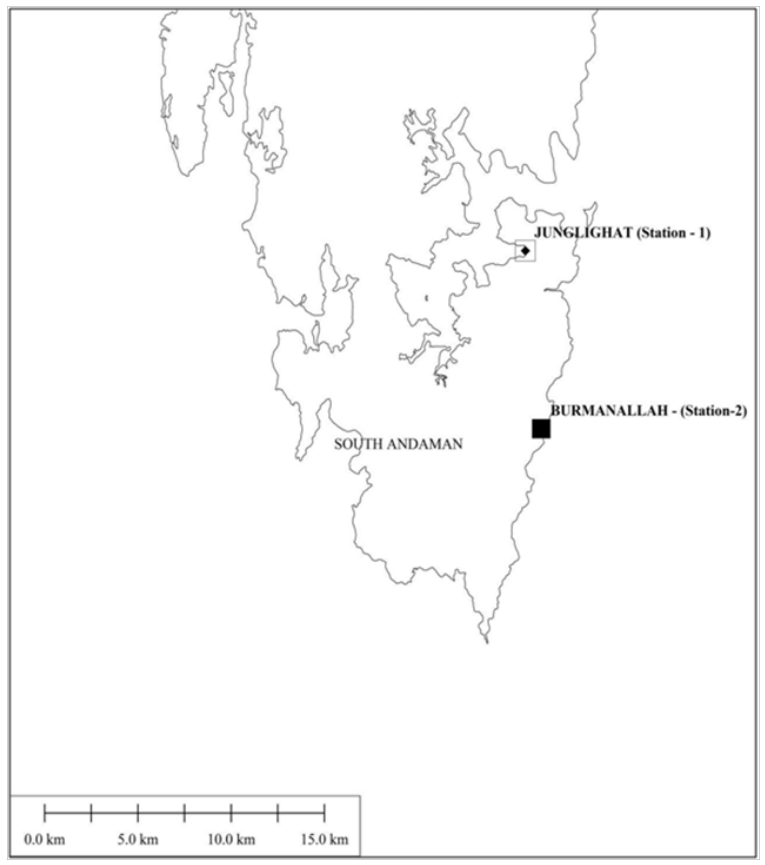

Figure I Map showing study locations, St. I (Junglighat) and St. 2 (Burmanallah).

\section{Results and discussion}

Correlation of GZP species with physico-chemical parameters

At St. 1, water temperature ranged from $27{ }^{\circ} \mathrm{C}-33{ }^{\circ} \mathrm{C}$, Salinity from $30 \%$ - 33\%, pH between 6.9 - 8.6 and Dissolved oxygen ranged from $3.1 \mathrm{mg} / \mathrm{L}-4.9 \mathrm{mg} / \mathrm{L}$. At St- 2, somewhat stable condition prevailed, water temperature ranged from $27^{\circ} \mathrm{C}-28^{\circ} \mathrm{C}$, salinity $(30 \%$ - 33\%o), $\mathrm{pH}$ between 7 - 8.6 and DO ranged from $3.1 \mathrm{mg} / \mathrm{l}-4.9 \mathrm{mg} / \mathrm{l}$. A wide variation in water temperature was recorded at St. 1, while other parameters showed a relatively closer similarity in its ranges between the stations.

During the study, four species of medusae showed a positive correlation with salinity, viz, Eireneceylonensis (correlation coefficient $\mathrm{r}=0.048)$, Eirenehexanemalis $(\mathrm{r}=0.08)$, Helgicirrhamalayensis $(\mathrm{r}=$ 0.065), Octophialuciumindicum $\quad(\mathrm{r}=\quad 0.148)$. Whereas Leriopetetraphylla showed a positive correlation with dissolved oxygen (0.229). Ctenophore species Pleurobranchiapileus showed positive correlation with both $\mathrm{pH}(\mathrm{r}=0.151)$ and $\mathrm{DO}(\mathrm{r}=0.602)$. Chaetognath species Sagittaenflata showed a positive correlation with salinity $(\mathrm{r}=$ $0.246)$ and dissolved oxygen $(r=0.615)$. Sagittameenakshiae showed positive correlation with all three factors other than temperature. The single representative of Thaliacea Thaliademocratica showed positive correlation with salinity $(\mathrm{r}=0.140)$. Among Larvaceans Oikopleurasp. showed a positive correlation with salinity, $\mathrm{pH}$ and DO, where as its sister taxa Fritillariasp.showed positive correlation with temperature and salinity. The correlation coefficient values of Siphonophores, Diphyeschamissonis that showed correlation with DO $(\mathrm{r}=0.314)$, Bassiabassensis correlation with salinity $(\mathrm{r}=0.286)$, Eudoxoidesspiralis correlation with DO $(\mathrm{r}=0.221)$, Eudoxoidesmitra correlation with DO $(\mathrm{r}=$ 0.227), Diphyesbojani showed negative correlation to all the factors. Late trochophore larvae showed a positive correlation with $\mathrm{pH}(\mathrm{r}=$ $0.635)$, fish embryo showed positive correlation with salinity $(\mathrm{r}=$ $0.603)$ and $\mathrm{pH}(\mathrm{r}=0.226)$. Flat worm larvae showed positive correlation with $\mathrm{pH}(\mathrm{r}=0.309)$ and DO $(\mathrm{r}=0.065)$. Ophiopluteus larvae showed positive correlation with all factors other than temperature, salinity $(\mathrm{r}$ $=0.272), \mathrm{pH}(\mathrm{r}=0.340), \mathrm{DO}(\mathrm{r}=0.026)($ Table 3$)$.

\section{Species composition and abundance}

A total of 16 species of GZP plus 3 different larval forms and late and early developmental stages of fish embryo were recorded overall during the study period. Medusoid forms were represented by two orders Leptomedusae and order Trachymedusae. Leptomedusae include species such as Eirenehexanemalis, Eireneceylonensis, Helgicirrahamalayensis, and Octophialuciumindicum. Order Trachymedusae was represented by Leriopetetraphylla. Ctenophores had a single representative species Pleurobranchiapileus. Two species of Chaetognaths- Flaccisagittaenflata and Sagittameenakshiae was recorded during the study period. The damaged specimens of Chaetognaths were categorized as Sagittasp. Two major taxa of urochordates, Larvacea and Thaliacea was recorded during this study, the larvacean taxa was represented by two species viz, Oikopleurasp. and Fritillariasp. Thaliacean taxon was represented by a single species, Thaliademocratica. Five different species of Siphonophores was encountered during this study wiz, Diphyeschamissonis, Bassiabassensis, Eudoxoidesspiralis, Eudoxoidesmitra and Diphyesbojani. Three different larval forms such as Late Trochophore, flatworm larvae and Ophiopluteus larvae were recorded totally. Fish eggs were observed in samples of both 
stations. Distribution of species across the study area is depicted in Table-1. Variation in the abundance and diversity of different gelatinous zooplankton taxa was observed during this study. At St. 1 Hydromedusae was the most abundant group of Gelatinous Zooplankton during the study period $\left(6.01 \mathrm{ind} / \mathrm{m}^{3}\right)$. Chaetognaths comprised the second most abundant group $\left(1.64 \mathrm{bind} / \mathrm{m}^{3}\right)$ followed by Ctenophores $\left(1.21 \mathrm{ind} / \mathrm{m}^{3}\right)$, Siphonophores $\left(1.21 \mathrm{ind} / \mathrm{m}^{3}\right)$, Thaliaceans $\left(0.7 \mathrm{ind} / \mathrm{m}^{3}\right)$, fish embryo $\left(0.45 \mathrm{ind} / \mathrm{m}^{3}\right)$ and Larvaceans $\left(0.14 \mathrm{ind} / \mathrm{m}^{3}\right)$ and late trochophore larvae $\left(0.01 \mathrm{ind} / \mathrm{m}^{3}\right)$ (Figure 4$)$. St. 2 Larvaceans was the most abundant group $\left(1.12 \mathrm{ind} / \mathrm{m}^{3}\right)$ followed by Chaetognaths $\left(0.88 \mathrm{ind} / \mathrm{m}^{3}\right)$, late trochophore larvae $\left(0.81 \mathrm{ind} / \mathrm{m}^{3}\right)$, Fish embryo $\left(0.43 \mathrm{ind} / \mathrm{m}^{3}\right)$, Siphonophores $\left(0.19 \mathrm{ind} / \mathrm{m}^{3}\right)$, Thaliacea $\left(0.11 \mathrm{ind} / \mathrm{m}^{3}\right)$, Flatworm larvae $\left(0.03 \mathrm{ind} / \mathrm{m}^{3}\right)$ Ophioplutieus larvae $\left(0.03 \mathrm{ind} / \mathrm{m}^{3}\right)$, while Hydromedusae were recorded at a lowest abundance value of (0.007 ind $/ \mathrm{m}^{3}$; (Figure 5).

Ctenophores were represented by a single species Pleurobranchiapileus, and it was restricted to St. 1, its positive correlation with $\mathrm{pH}$ and DO indicating higher abundance in St. 1. High $\mathrm{pH}$ and higher DO values at St. 2 was also observed compared to St. 1 but this locality failed to promote proliferation of Ctenophores. Chaetognaths were the second most dominant taxa in both station, their active predatory nature and higher adaptability to varying abiotic factors indicate their successful distribution. The single species of Doliolids, Thaliademocratica was recorded from both stations; they showed a positive correlation with salinity, with an optimum range of 30psu-33 psu recorded during the study period. Two species of Siphonophores, Eudoxoidesspiralis and Eudoxoidesmitra were restricted to St. 1 and showed positive correlation with DO. Whereas, Bassiabassensis were restricted to St. 2 where it showed positive correlation with salinity and DO. Two different life stages of Bassiasp. such as eudoxoid and polygastric stages were observed during the months of December-13 and February-14, indicating their reproductive developmental period. Diphyeschamissonis and Diphyesbojani were recorded from both stations. Diphyesbojani showed negative correlation to all physicochemical factors and $D$. chamissonis showed positive correlation with DO. Both solitary and aggregate life forms were recorded during the months of December-13 and February-14.

Dendrogram (Figure 2) produced from square root transformed group average data showed clustering of St. 1 and St. 2 samples showed $23.01 \%$ similarity due to the occurrence of common taxa (such as Chaetognaths, Hydromedusae and Fish embryo) in both stations, cluster formed in St. 1 between all the samples showed a similarity of $30.64 \%$, whereas the same in St. 2 showed a higher similarity of $36.59 \%$ indicating even distribution of taxa in St. 2. Cluster with highest similarity $(63.57 \%)$ at St. 1, formed between samples JNMAR-13 and JNAPL-13 (JN=Junglighat; March - April'13) followed by the cluster formed between samples BHAUG-13 and BHFEB-14 (61.27\%) from St. 2 (BH= Burmanallah; Aug'13 \& Feb'14). The cluster with least similarity (33.48\%) among the stations was observed in St. 1 between samples of JNDEC-13 and JNAUG-13 followed by $39.69 \%$ similarity, resulted by the aggregation of samples of JNFEB-13, JNMAR-13 and JNAPL-13. MDS (multi-dimensional scaling) ordination (Figure 3 ) on 'GZP' community abundance square root transformed data showed, formation of two distinct aggregations among Samples of St. 1 and St. 2 respectively at a stress of 0.1. The samples of St. 2 were clustered in least distance indicating their higher similarity than St. 1 as observed in the dendrogram. The higher dissimilarity between the monthly samples at St. 1 was due to high species diversity where each species showed a maximum density according to availability of optimal conditions compared to St. 2, that made the samples more dissimilar. Due to lower species diversity at St. 2, this locality became less competitive for gelatinous species, so the endemic gelatinous species at St. 2 showed much stable occurrence in all the collected samples which made the samples more similar, and aggregation of samples (Figure 3). Graph showed stress values of 0.1 that corresponded to a good ordination with no misleading interpretation. ${ }^{33}$

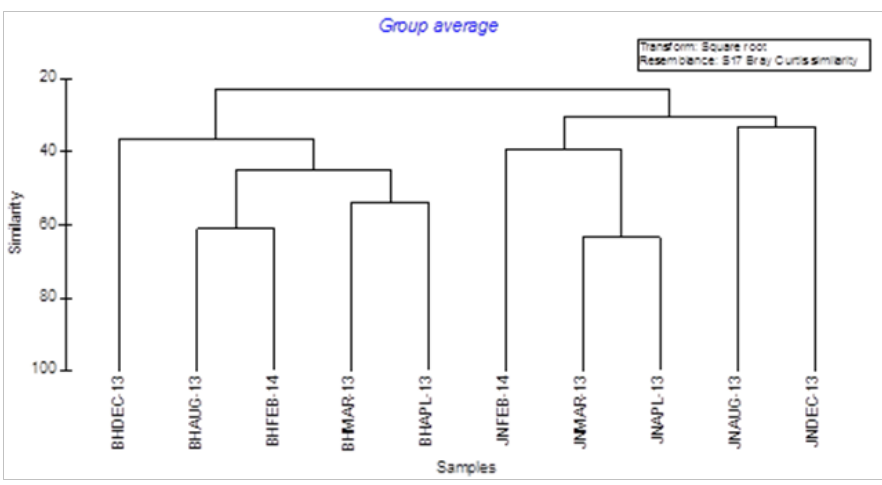

Figure 2 Bray Curtis similarity dendrogram showing similarity between St. I and St. 2.

*(JN indicates St. I AND BH indicates St. 2).

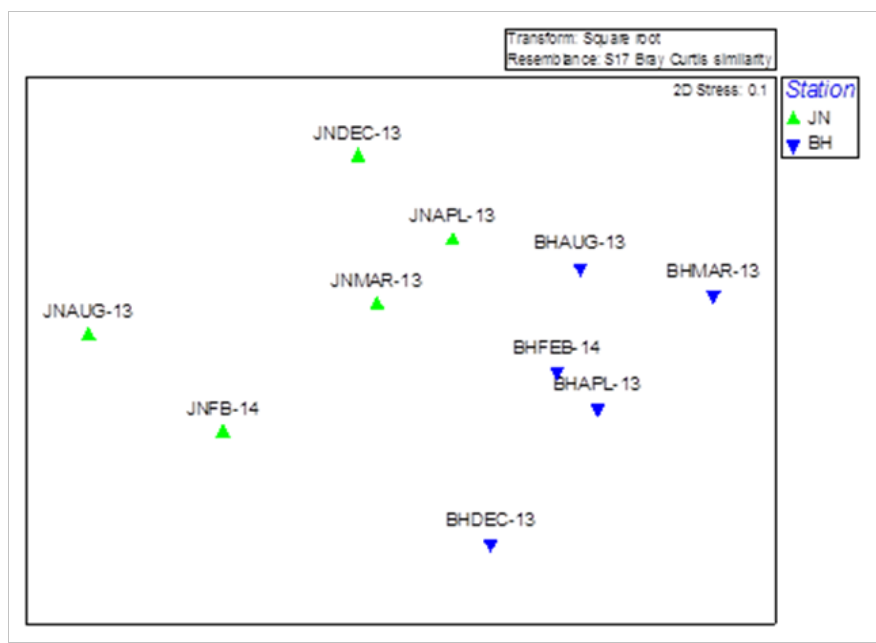

Figure 3 MDS showing spatial distribution of gelatinous zooplankton at St. I \& St. 2.

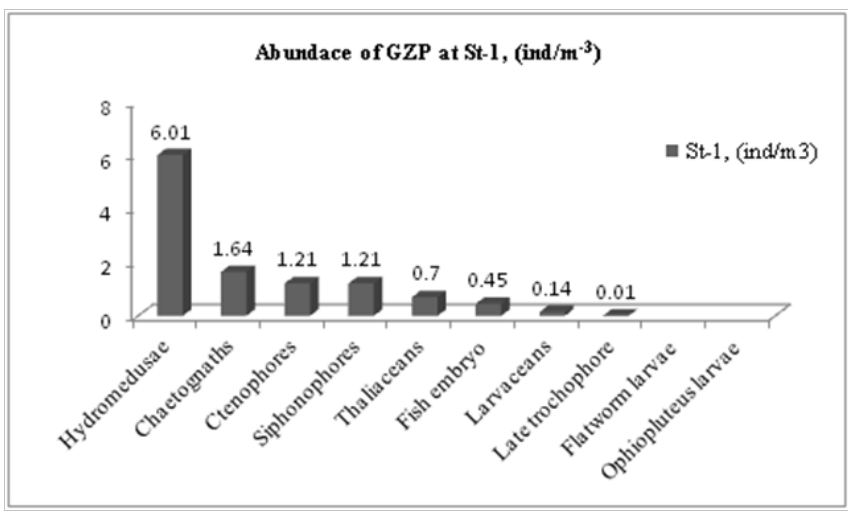

Figure 4 Abundanceof different GZP taxa at St. I. 


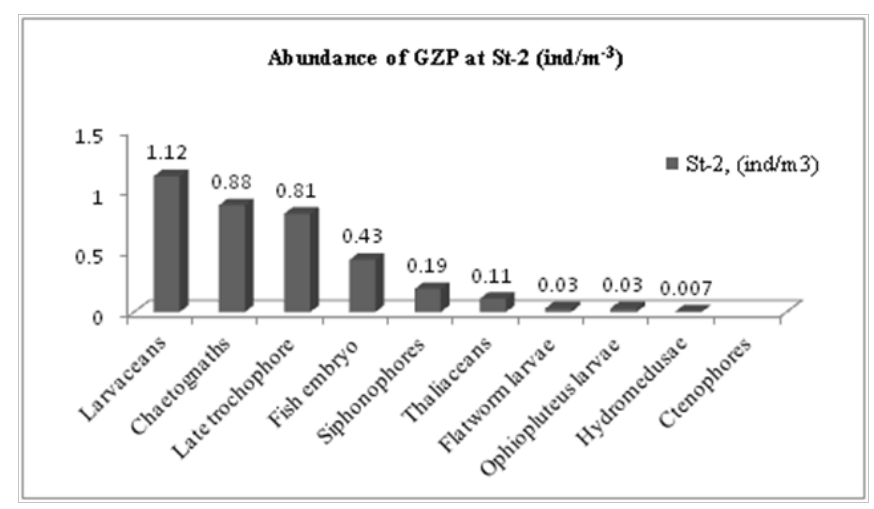

Figure 5 Abundance of different GZP taxa at St. 2.

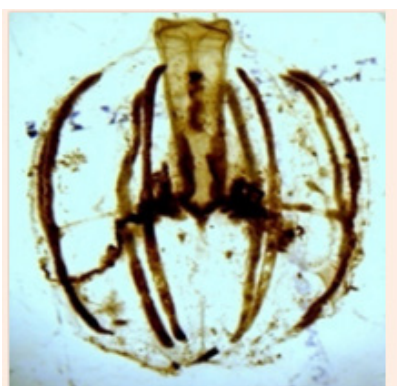

Pleurobranchiapileus

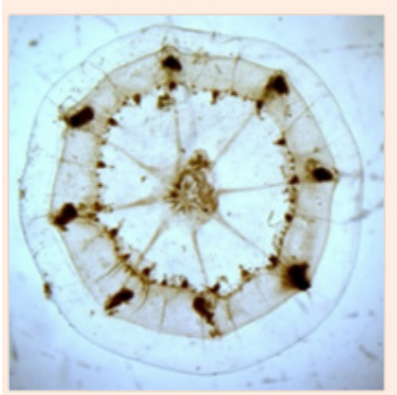

Octophialuciumindicum

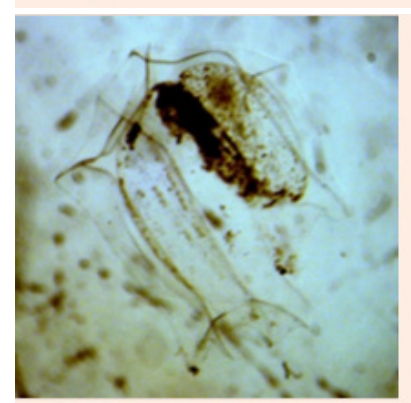

Bassiabassensis

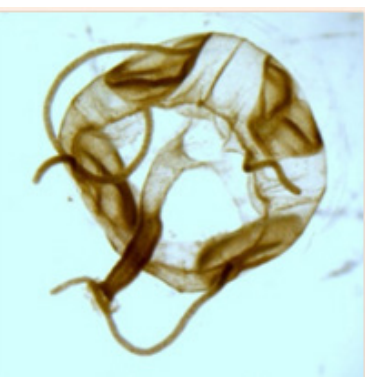

Leriopetetraphylla

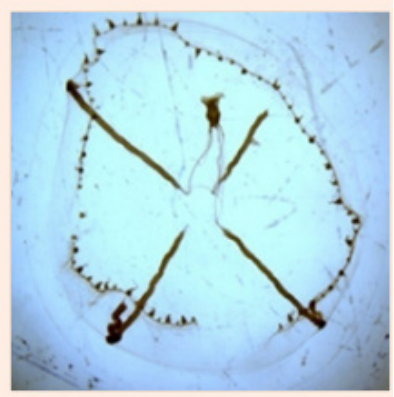

Eireneceylonensis

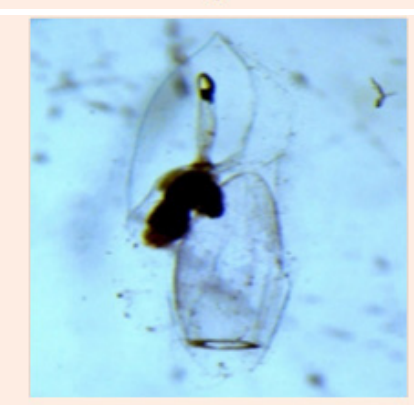

Diphyeschamissonis
Figure 6 Gelatinous species identified during the study period.

The abundance of gelatinous zooplankton in St. 1 was comparatively higher than St. 2. Bio-Geographic variation of both stations is primary factor promoting periodic successful diversity and survival of various 'GZP' taxa. St. 1 is a bay region, land logged condition, here diminish wind driven water circulation, and culminate in high temperature, salinity which promote nutrient enrichment. ${ }^{34}$ This region is a major harbor in Port Blair; it is polluted due to in higher anthropogenic activity. Both study area had almost similar range of physicochemical variations, and relatively equal amount of fish embryo to promote the proliferation of gelatinous zooplankton, though few taxa showed a restricted distribution in both areas. Both stations had similar salinity range of $30 \%$ - $33 \%$ even though Leptomedusaeviz, Eirenehexanemalis, Eireneceylonensis,

Helgicirrahamalayensis, and Octophialuciumindicum showed restricted distribution at St. 1, these species showed a positive correlation with salinity. The Trachymedusae Leriopetetraphylla was dominant group of medusae among the stations which showed a positive correlation with DO. DO range of $3.5 \mathrm{mg} / 1-4.5 \mathrm{mg} / \mathrm{l}$ was optimum for this species. This was the only species of medusae recorded from both the stations, showing a broad range of geographic distribution. Occurrences of low density from the samples with high DO value were noted during this study. Purcell ${ }^{35}$ stated that warm water temperature and higher salinity promoted asexual reproduction of medusae but it was not so in this study area i.e. at St. 2 where similar conditions prevailed, which may point out the influence of geographic differences in both stations and variation of anthropogenic activity. The DO values at St. 1 was comparatively lower than St. 2 which lead to slight hypoxic condition promoting aggregation of medusae in terms of density and diversity as observed in this study has been reported earlier (Purcell et al., 2001b). ${ }^{35}$ All the medusae forms recorded during the present study were previously reported from Andaman Sea. ${ }^{3}$

The 'GZP' taxa in the both stations showed wide variation in distribution which is influenced by many factors, such as physicochemical parameters, geographical features of locality, anthropogenic influence, pollution, less abundance of predators and availability of food source etc. St. 2 showed high abundance of Larvaceans whereas St. 1 showed high abundance of hydromedusae. Both study regions had almost similar ranges of abiotic factors but it was not enough to support domination of other gelatinous taxa such as medusae and ctenophores in St. 2. This highlights the role of geographic locality features and anthropogenic activity as the key determinant factor in distribution and proliferation of gelatinous zooplankton taxa.

At St. 2 Larvaceans were most abundant taxa with two representatives Oikopleurasp. and Fritillariasp. Both species showed positive correlation with physico-chemical factors. Lesser anthropogenic influence, low pollution rate and absence of geographical barriers promoted the Larvaceans to dominate in St. 2. In St. 2 physico-chemical factors was the key determinant of species distribution, and abundance. Taxon influenced by more than one abiotic factors showed better adaptive capability and wide range of distribution even if they consist of low species richness. St. 2 i.e. Burmanallah is an active fishing zone in Port Blair, which lead to the occurrence of lower abundance of ichthyoplanktons here. This ichthyoplankton deficiency was linked with the distribution and diversity of 'GZP' taxa, as it is a major component in the diet of adult and juvenile gelatinous carnivores. The complexity of St. 1 was due to its higher diversity, which is contributed by relative abundance of each species in St. 1. Evenness of 'GZP' taxa compared the relative similarity of population size of corresponding taxa. Hydromedusae was the taxa with highest species richness $(d=5)$, even though this taxa showed discontinuous occurrence in sample resulted in evenness value 0.6036 from St. 1, in St. 2 this taxa showed a very low evenness (0.007) and species richness ( $d=1$; Table 2). Similarly, siphonophores and ctenophores showed higher diversity at St. 1. Whereas the rest of the taxa showed a higher diversity at St. 2, these taxa had similar 
species richness as found in St. 1, the higher evenness value of these groups recorded from St. 2 (Table-2). Among the 'GZP' taxa showed abrupt increase in population size particularly hydromedusae, ctenophores compared to other individual taxa during the study period at St. 1 indicating their ability to thrive in polluted environment. Their confined distribution and high diversity, indicates that these taxa chose suitable environmental condition to proliferate and dominate in particular habitats. ${ }^{36-40}$

Table I List of species recorded during the study period from St.I \& St. 2

\begin{tabular}{|c|c|c|c|c|c|c|c|c|c|c|}
\hline \multirow[b]{2}{*}{ Species name $\&$ Larvae types. } & \multicolumn{3}{|c|}{ Station- I ( Junglighat ) } & \multicolumn{7}{|c|}{ Station-2 ( Burmanallah ) } \\
\hline & Mar- I 3 & Apr-13 & Aug- 13 & Dec- 13 & Feb- I 4 & Mar- I3 & Apr- I 3 & Aug-13 & Dec-13 & Feb- I 4 \\
\hline Eireneceylonensis & + & + & + & + & + & - & - & - & - & - \\
\hline Eirenehexanemalis & + & + & + & + & + & - & - & - & - & - \\
\hline Helgicirrahamalayensis & + & - & + & + & + & - & - & - & - & - \\
\hline Octophialuciumindicum & + & $\overline{+}$ & - & - & + & - & - & - & - & - \\
\hline Leriopetetraphylla & + & + & $\overline{+}$ & $\overline{+}$ & - & - & - & - & $\overline{+}$ & - \\
\hline Pleurobranchiapileus & + & + & + & + & $\overline{+}$ & - & - & - & - & - \\
\hline Sagitta sp. & + & + & _- & + & - & $\bar{t}$ & $\overline{+}$ & $\bar{t}$ & $\overline{+}$ & $\overline{+}$ \\
\hline Flaccisagittaenflata & + & _- & $\overline{+}$ & + & $\overline{+}$ & _- & - & _- & + & - \\
\hline Sagittameenakshiae & + & - & - & _- & + & - & - & - & + & - \\
\hline Thaliademocratica & - & - & - & - & + & - & $\overline{+}$ & - & + & $\overline{+}$ \\
\hline Oikopleurasp. & $\overline{+}$ & $\overline{+}$ & - & $\bar{t}$ & - & - & + & $\overline{+}$ & + & + \\
\hline Fritillariasp. & + & + & - & - & - & - & + & + & + & + \\
\hline Diphyeschamissonis & + & - & $\overline{+}$ & - & $\bar{t}$ & - & - & + & + & + \\
\hline Bassiabassensis & - & - & - & - & _- & - & - & _- & + & + \\
\hline Eudoxoidesspiralis & - & - & $\overline{+}$ & - & $\overline{+}$ & - & - & - & - & - \\
\hline Eudoxoidesmitra & - & - & + & - & - & - & - & - & - & - \\
\hline Diphyesbojani & - & - & + & - & $\bar{t}$ & - & $\bar{t}$ & - & - & - \\
\hline Late trochophore & $\bar{t}$ & - & - & $\bar{t}$ & _- & $\bar{t}$ & + & $\overline{+}$ & $\overline{+}$ & $\overline{+}$ \\
\hline Fish embryo & + & $\overline{+}$ & - & _- & $\bar{t}$ & + & + & + & + & + \\
\hline Flatworm larvae & - & - & - & - & - & + & + & - & - & + \\
\hline Ophiopluteus larvae & 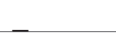 & 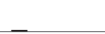 & - & - & - & $\ldots$ & $\ldots$ & - & + & - \\
\hline
\end{tabular}

Table 2 Species Richness (d), Species Abundance (ind $/ \mathrm{m}^{3}$ ) and Pielou's Evenness (J') of individual taxa from St-I and St-

\begin{tabular}{|c|c|c|c|c|c|c|}
\hline \multirow[b]{2}{*}{ Taxa } & \multicolumn{3}{|c|}{ Station I } & \multicolumn{3}{|c|}{ Station 2} \\
\hline & d & Ind $/ \mathrm{m}^{-3}$ & J' & d & Ind/m-3 & J' \\
\hline Hydromedusae & 5 & 6.01 & 0.6036 & I & 0.007 & 0 \\
\hline Ctenophores & I & 1.21 & 0.7962 & 0 & 0 & 0 \\
\hline Chaetognaths & 2 & 1.64 & 0.7501 & 2 & 0.88 & 0.8493 \\
\hline Thaliaceans & I & 0.7 & 0 & I & 0.11 & 0.7385 \\
\hline Larvaceans & 2 & 0.14 & 0.346 & 2 & 1.12 & 0.6062 \\
\hline Siphonophores & 4 & 1.21 & 0.3981 & 3 & 0.19 & 0.944 \\
\hline Late trochophore & I & 0.01 & 15 & I & 0.81 & 0.8649 \\
\hline Flatworm larvae & 0 & 0 & 0 & I & 0.03 & 0 \\
\hline Ophiopluteus larvae & 0 & 0 & 0 & I & 0.03 & 2.164 \\
\hline Fish embryo & I & 0.45 & 0.4947 & I & 0.43 & 0.9982 \\
\hline
\end{tabular}

Table 3 Spearman rank correlation $(r)$ between various environmental partameters

\begin{tabular}{|c|c|c|c|c|}
\hline Species Name & Temperature (OC) & Salinity (psu) & pH & Dissolved oxygen (mg/l) \\
\hline Eireneceylonensis & -0.01472 & 0.004873 & -0.19127 & -0.14095 \\
\hline Eirenehexanemalis & -0.06968 & 0.089099 & -0.08802 & -0.14909 \\
\hline Helgicirrhamalayensis & -0.08556 & 0.065264 & -0.09636 & -0.13473 \\
\hline Octophialuciumindicum & 0.061611 & 0.148222 & -0.13587 & -0.25674 \\
\hline Leriopetetraphylla & -0.02036 & -0.44054 & -0.31876 & 0.229053 \\
\hline Pleurobranchiapileus & -0.18516 & $-0.4077 \mid$ & 0.151079 & 0.602199 \\
\hline Sagittasp. & 0.809217 & 0.190319 & -0.37462 & -0.5435 \\
\hline Flaccisagittaenflata & -0.07557 & 0.246785 & -0.20892 & 0.615879 \\
\hline Sagittameenakshiae & -0.09129 & 0.517333 & 0.005187 & 0.504622 \\
\hline Thaliademocratica & -0.02537 & 0.140593 & -0.11705 & -0.22112 \\
\hline Oikopleurasp. & -0.0518 & 0.592223 & 0.156927 & 0.120836 \\
\hline Fritillariasp. & 0.026849 & 0.380363 & -0.17977 & 0.486524 \\
\hline Diphyeschamissonis & -0.02746 & -0.37157 & -0.35432 & 0.314137 \\
\hline Bassiabassensis & -0.02756 & 0.286319 & -0.1058 & 0.11691 \\
\hline Eudoxoidesspiralis & -0.02035 & -0.44205 & -0.3252 & $0.22|44|$ \\
\hline Eudoxoidesmitra & -0.01961 & -0.44444 & -0.32034 & 0.227831 \\
\hline Diphyesbojani & -0.08422 & -0.15439 & -0.22157 & -0.09045 \\
\hline Late trochophore & $-0.397 \mid$ & -0.09493 & 0.635538 & -0.14097 \\
\hline Fish embryo & -0.00595 & 0.60308 & 0.226965 & -0.7091 \\
\hline Flatworm larvae & -0.21569 & -0.44444 & 0.309836 & 0.065094 \\
\hline Ophiopluteus larvae & -0.28818 & 0.272166 & 0.34088 & 0.026575 \\
\hline
\end{tabular}




\section{Conclusion}

This study is the first report on distribution of gelatinous zooplankton from the coastal waters of Port Blair, South Andaman. In the present study, a total of sixteen species of 'GZP' belonging to ten taxa such as medusae, ctenophores, Chaetognaths, Appendicularians, Doliolids, Siphonophores and developmental stages of four different taxa was identified. A variation in species composition between St. 1 and St. 2 were recorded. Gelatinous species vizPleurobranchiapileus, Eudoxoidesspiralis, Eudoxoidesmitra, Eireneceylonensis, Eirenehexanemalis, Helgicirrahamalayensis, and Octophialuciumindicum showed restricted distribution to St. 1. At St. 2 species such as Bassia bassensis, Ophiopluteuslarvae, and flatworm larvae showed restricted distribution. This study indicates that St. 1 had a higher abundance of gelatinous zooplankton than that of St. 2, and their abundance and successful diversity is governed by factors viz geographical features of locality, anthropogenic activity, availability of dietary source, extent of pollution, fishing activity, physicochemical variations and lack of predators. The inability of St. 2 to accommodate a diverse population of 'GZP' was due to the variation in these governing factors. The lower similarity between the samples of St. 1 is due to periodic dominance of individual gelatinous taxa, creating variation in species diversity.

\section{Acknowledgments}

None.

\section{Conflicts of interest}

None.

\section{References}

1. Bhattathiri PMA, Devassy VP. Primary productivity of the Andaman Sea. Indian J Mari Sci. 1981;10:243-247.

2. Vannucci M, Navas D. On ecology of indian ocean hydromedusae, IOBC Handbook. 1973;5:1-54.

3. Santhakumari V. A study of Medusa from Andaman and Nicobar waters. J ZoolSoci Ker. 1993;3(1):37-43.

4. Kumar SB, Panigrahy RC. Jellyfish bloom along the south Odisha coast, Bay of Bengal. J Current Sci. 2013;104(4):25.

5. Santhakumari V. Medusa from sea around Laccadive group of islands $\left(7^{\circ}-18^{\circ} \mathrm{N} / 69^{\circ}-76^{\circ} \mathrm{E}\right)$ proc. second workshop scient,result, FORV sagarsampada. 1996;pp.249-255.

6. Santhakumari V. Species composition, distribution and abundance of hydromedusae in the exclusive economic zone of the east coast of india. JSeto Mar Bioi Lab. 1997;38(112):53-61.

7. Santhakurnari V, Tiwari LR, Nair VR. Species composition, abundance and distribution of hydromedusae from dharamtar estuarine system, adjoining bombay harbor. Indian J of Mar Sci. 1999;pp.158-162.

8. Ganapati PN, Nagabhushanam R. Seasonal distribution of the hydromedusae off the Visakhapatnam coast. J. Mem. Oceanogr. Andhra Univ Ser. 1958;62:91-99.

9. Venkataraman K, Wafar M. Coastal and marine biodiversity of India. Indian J Marine Sci. 2005;34:57-75.

10. Hamner WM, Madin LP, Alldredge AL, et al. Underwater observations of gelatinous zooplankton:sampling problems, feeding biology, and behavior. J Limnol Oceanogr. 1952;20(6):907-917.

11. Raskoff KA, Sommer FA, Hamner WM, et al. Collection and Culture Techniques for Gelatinous Zooplankton, Marine Biological Laboratory. J Biol Bull. 2003;204:68-80.
12. Iyyapparajanarasimapallavan G. Distribution and abundance of gelatinous zooplankton along tamilnadu coastal waters. J Biol Sci. 2013;13(1):18-25.

13. Gibbons MJ, Richardson AJ. Beyond the jellyfish joyride and global oscillations: advancing jellyfish research, $J$ Plankton Res. 2013;35(5):929-938.

14. Canepa A, Fuente V, Sabatés A, et al. Pelagianoctiluca in the Mediterranean sea (e-Book) springer Dordrecht, Heidelberg, new york London. 2014

15. Dong Z, Liu D, Keesing JK. Jellyfish blooms in china: dominant species, causes and consequences, J Mar Poll Bul. 2010;60(7):954-963.

16. Fleming NEC, Harrod C, Houghton JDR. Identifying potentially harmful jellyfish blooms using shoreline surveys. $J$ Aquaculture EnviInterct. 2013;4:263-272.

17. Kaneda A, Kohama T, Kawamura Y, et al. Periodicity in the accumulation of gelatinous zooplankton during the summer season in the coastal area of iyo-nada, J Japan Limnol. Oceanogr. 2007;52(2):707-715.

18. Arai MN. Predation on pelagic Coelenterates: A review. J Mar Biol. $2005 ; 85: 523-536$

19. Buecher E, Goy J, Planque B, Etienne M, et al. Long-term fluctuations of Liriopetetraphyllain Villefranche Bay between 1966 and 1993 compared to Pelagianoctiluca pullulations. J OceanolActa. 1997;20:145-157.

20. Graham WM, Bayha KM. Biological invasions by marine jellyfish. In: Nentwig W (Eds.), Ecological studies, J Biologicallnvas. SpringerVerlag, Berlin. 2007;pp:240-255.

21. Omor M. Zooplankton fisheries of the world: a review. J Mar Biol. 1978;48:199-205.

22. Hung JJ, Hung CS, Su HM. Biogeochemical responses to the removal of maricultural structures from an eutrophic lagoon (tapong bay) in taiwan. J Mar Env Res. 2008;65:1-17.

23. Masilamoni JG, Jesudossk KS, Nandakumar KK, et al. Jellyfish ingress: a threat to the smooth operation of coastal power plants. JCurrent Sci. 2000;79(5):569.

24. Matsueda N. Presentation of Aurelia aurita atthermalpower station. Bull Mar BiolStnAsamushi. 1969;13:187-191.

25. Yasuda T. Studies on the common jelly-fish, Aurelia aurita(Linne). Jpn Fish Resour Cons Assoc, Tokyo (in Japanese with English abstract). 1988.

26. Rodríguez JS, Martínez NLL. Isolation and prepurification of active compounds in venom from Pelagianoctiluca(Scyphozoa: Pelagiidae) from the Caribbean Sea ,J Ciencias Marinas. 2011;37(3):369-377.

27. UNESCO. Zooplankton sampling Monographs on Oceanography Methodology 2, UNESCO, Paris. 1968.

28. Strickland JDH, Parsons TRA practical handbook of seawater analysis. Bulletin of the Fisheries Research Board of Canada, 167(2):310.

29. Conway DVP, White RG, Ciles JHD, et al. Guide to coastal surface zooplankton of the south western Indian ocean, occasional publication of the marine biological association of the United Kingdom,no i5, Playmouth, UK. 2003

30. Perry RA. guide to the marine plankton of southern California (3rd Edn), UCLA OceanGLOBE and Malibu High School. 2003;1-319.

31. Conway DVP. Marine zooplankton of southern Britain. Part 1: Radiolarian, Helizoa, Foraminifera, Ciliophora, Cnidaria, Ctenophora, Platyhelminthes, Nemertean, Rotifer and Mollusca AWG. John. Occasional publications. Marine biological association of the United Kingdom, UK. 2012;pp.1-138. 
32. Zhengzhong Marine plankton, china ocean press, Beijing, ISBN. 1989:3-540-15720-15724.

33. Clarke KR, Warwick RM. Change in Marine Communities: An Approach to Statistical Analysis and Interpretation. PRIMER-E, Plymouth, UK 2001;pp.38.

34. Papathanassiou E, Panayotidis P, Anagnostaki K. Notes on the biology and ecology of the jellyfish Aurelia aurita Lam. In Elefsis Bay (Saronikos Gulf, Greece). PSZNI: J MarEcol. 1987;8(1):49-58.

35. Purcell JE, Arai MN. Interactions of pelagic cnidarians and ctenophores with fish: a review. J Hydrobiol. 2001;451(155):27-44.

36. Arai MN. Pelagic coelenterates and eutrophication: a review. $J$ Hydrobiol. 2001;155:69-87.
37. Fernandes V, Ramaiah N. Distributional Characteristics of surfacelayer mesozooplanktons in the Bay of Bengal during the 2005 winter monsoon. Indian J Geo-Marine Sci. 2014;43(2):176-188.

38. Oueda A, Wgueda, Kabre AT, et al. Diversity, abudance and seasonal dynamics of zooplankton community in south saharan reservoir (burkinafaso) J Biol Sci. 2007;7:1-9.

39. Purcell EJ, Uye SI, Lo WT. Anthropogenic causes of jelly fish blooms and their direct consequences for humans: A review. J Mar Ecol Prog. 2007;350:153-174.

40. Qazim SZ Anzari ZA. Food components of Andaman Sea. Indian J Mar Sci. 1981;10:276-279. 